\title{
Irish Chefs and Restaurants in the Geography of "Local" Food Value Chains
}

\author{
Leslie A. Duram ${ }^{*}, 1$ and Mary Cawley ${ }^{2}$ \\ ${ }^{I}$ Geography \& Environmental Resources, Southern Illinois University, Carbondale, Illinois 62901, USA \\ ${ }^{2}$ School of Geography and Archaeology, National University of Ireland Galway, Galway, Ireland
}

\begin{abstract}
Restaurant chefs and owners have a potentially influential role to play in promoting the use of local foods and supporting producers. Indeed chefs are taste makers, and their conceptualization of local food can influence consumers' perceptions, knowledge and geographical awareness. Yet their role is not well documented in research literature. In-depth interviews were conducted with seven purposively selected chefs in Galway City, Ireland, who are seeking to develop a local cuisine. Menus, websites, and statements of philosophy were also analyzed. Attention focused on the definition of local food, sources of supply, how local food is used in cuisine, and how it is presented on menus. Common themes among restaurants include the geographic stretching of local food to include artisan products, issues of seasonality and variability in supply, and questions about the authenticity of promoting the use of local foods. There are opportunities for building linkages between chefs and local producers, to promote authentic use of locally sourced foods. Recommendations are made for five strategies to build a sustainable local food geography, based on strengthening the farmer- to-chef shortened value chain.
\end{abstract}

Keywords: Local food, chefs, restaurants, small scale producers, food value chain, Ireland.

\section{INTRODUCTION}

Local food has gained attention as an alternative to the current globalized food system, as consumers seek to reconnect with farmers, increase the natural and healthy foods in their diets, and support their local communities. Despite increased media attention and policy awareness, research indicates that the definition of "local food" is complex as are the implications for small scale producers [1-4]. It is a socially constructed concept which incorporates geographical locations, institutions and actors including producers, consumers and customers [5]. In the context of economic opportunities for producers, much attention has focused on shortened food value chains and the importance of direct sales to consumers in farmers' markets [6-8]. By contrast, less is known about the role of chefs as purchasers and users of local food in their restaurants and their relationships with producers.

While the produce purchased by an individual chef will usually only form part of a producer's sales, chefs are known to play an important role as taste makers among other chefs and among the public more generally [9]. Examples exist like Alice Waters, who established Chez Panisse in Berkeley, California, in 1971 [10], and Myrtle Allen of Ballymaloe House in Ireland [11] whose influence is recognized as having been far-reaching.

Restaurants have not been neglected in studies of food by geographers, sociologists, and cultural historians [9, 12-19]. However, local food has received relatively limited attention in studies of restaurants, and specifically the role of chefs in

*Address correspondence to this author at the Department of Geography \& Environmental Resources, Southern Illinois University, Carbondale, Illinois 62901, USA; Tel: + 618.453.6084; E-mail: duram@siu.edu the local food chain is under explored. Yet, this is important in understanding the market opportunities that exist for local food producers, which can impact geographical patterns of regional land use. The reported research had three main objectives: (1) to investigate how chefs as tastemakers define local food and why they use it in cuisine; (2) to shed light on where chefs source local food and the barriers, if any, that exist in sourcing it; and (3) to understand how chefs use and promote local food in their cuisine, as advertised on menus and websites. Particular emphasis is placed on identifying associations between local food and geographic place of production.

\section{DEFINING "LOCAL" FOOD}

"Local" has a series of different meanings in the context of food that relate to the place and methods of production and exchange, the factors that drive consumer demand, and the influence of producers in the food system [20]. Chefs operate within this broader framework. Thus local food has been defined in terms of distance from places of consumption, as reflected in the 100 mile diet [21] and from markets [22]. In some cases, political boundaries help delineate local food $[23,24]$. In other contexts, "Buy Irish" symbols or small German, Spanish or French flags on food are correlated to nationalism or patriotism. Regional labeling is well-established in the European Union (EU) and local labeling is growing in incidence [25, 26]. Local food is also described in the context of natural resource use and life-cycle assessment from farm to table [27, 28]. "Local" may capture features relating to production using low-input methods (such as organic farming); it may also convey personal contact between producers and consumers and exchange on the basis of trust [29-32]. Local food may be seen as part of a reaction to mass production and mass consumption and a 
quest for "authenticity" in the countryside [33, 34]; and a new agro-geography that considers food as more than a simple commodity [1]. Like organic, local has also been annexed in inauthentic ways by commercial producers [3538].

Local food is associated with consumers seeking high quality which they may define in terms of nutritional value, freshness, clean production, animal welfare, an absence of additives, avoidance of the risk posed by particular animal diseases and of the energy costs and environmental impacts of transporting food over long distances [4, 27, 39-43]. There is a concern with how nature is "used" rather than "abused" $[44,45]$. Some of these alternative constructions are reflected in the Slow Food movement, Community Supported Agriculture, and the increasing number of farmers' markets which link consumers more directly with the source of their food [46]. Additionally, the local is also conceived as a site of resistance where small scale producers and consumers contest the placelessness of globalized food production and regain geographic influences [8, 17, 47]. Chefs can support both consumers and farmers in this quest for alternative production and consumption.

\section{STUDY AREA}

In Galway, Ireland some chefs are actively seeking to establish a local food culture around values shared by both local consumers and tourists. Although a relatively small urban area (population 72,414 in 2006), Galway has access to sources of local food supplies (Fig. 1).

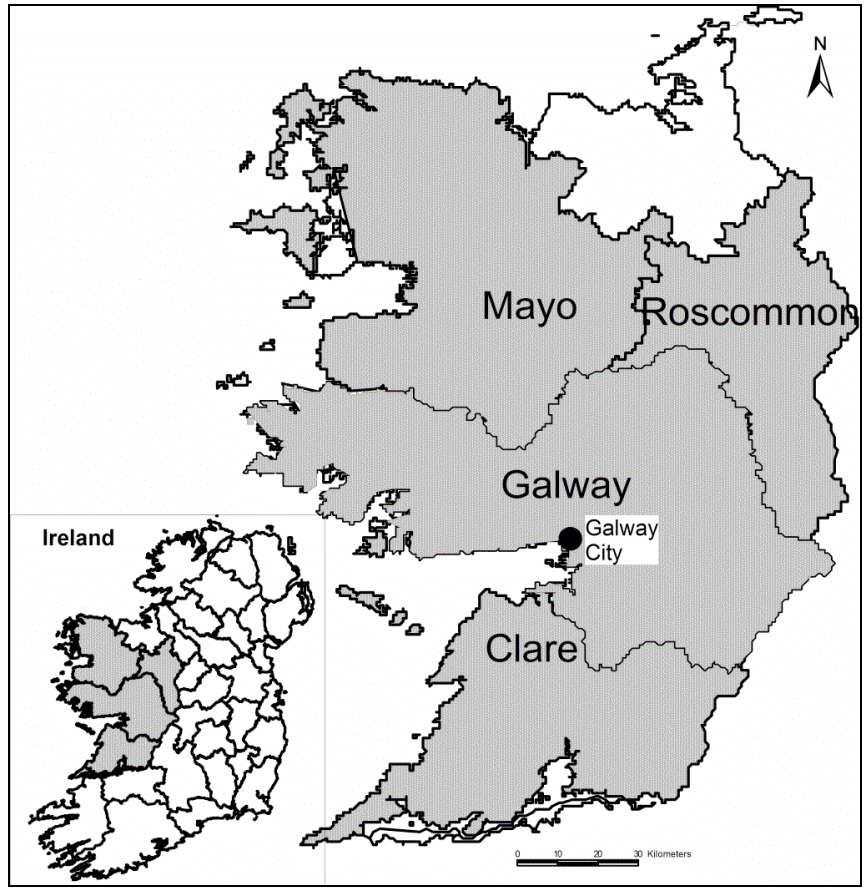

Fig. (1). Galway City and its hinterland.

Its location on the Atlantic coast, agricultural hinterland and temperate maritime climate are conducive to the supply of food from sea and land throughout much of the year. Limitations exist primarily relating to vegetables, with choice being constrained by climate and import of out of season and exotic fruit and vegetables being the norm. Established (smoked salmon and trout) and new specialty food products (air dried beef and lamb) are available. Connemara lamb from a mountainous area northwest of Galway City, holds a European Union (EU) Protected Geographical Indication (PGI) quality food label [48]. There are a handful of farm cheese producers and a small but growing number of organic vegetable and beef producers located in County Galway and in the adjoining counties of Roscommon and Clare. A traditional weekly farmers' market is frequented by a wide range of small scale food producers and processors (Figs. 2, 3).

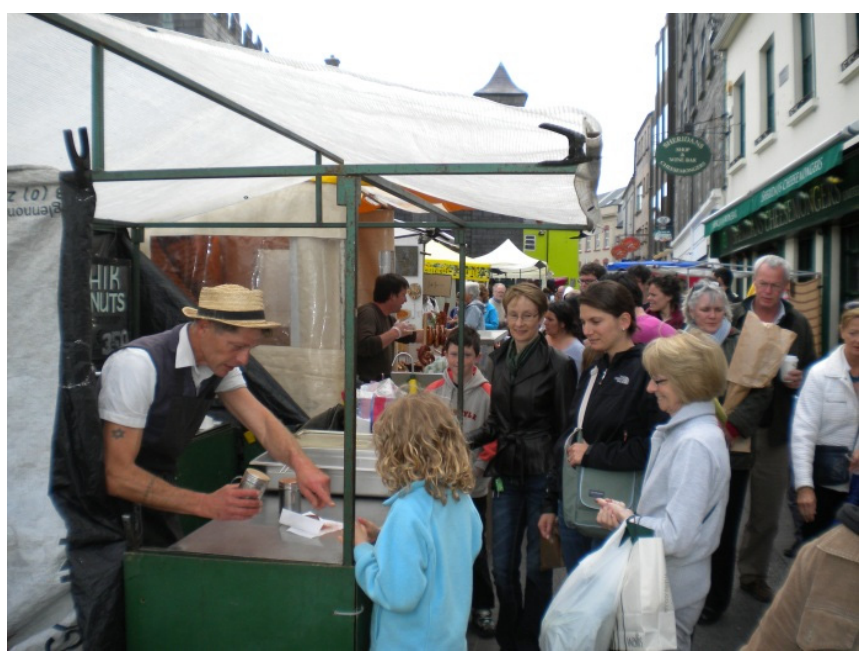

Fig. (2). Galway Farmer's Market with produce, artisan and local foods (here Donuts).

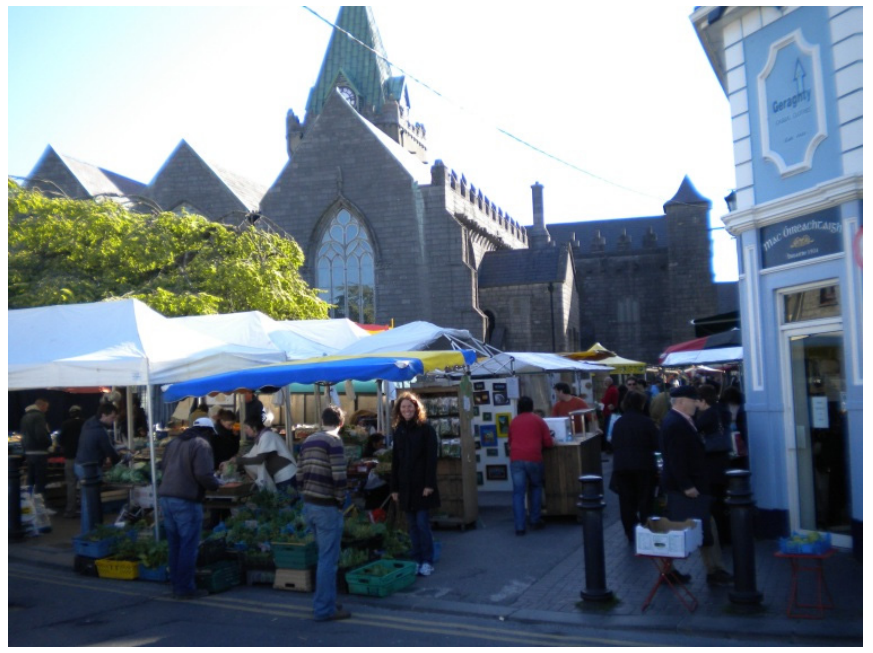

Fig. (3). Galway Farmers' Market is weekly, year around.

Galway has a well educated middle-class resident population with disposable income. It also has a developed tourist market and substantial demand for dining out, which is met by over 135 restaurants (there are also as many as pubs which serve food). A small number of these restaurants advertise their use of local produce and are recognized for doing so in national and international food guides.

\section{Irish Food}

Historically, the Irish ate meat, fish and vegetables produced under natural conditions in nearby areas [49]. Associations with place of production existed by necessity but were less formalized and commercialized than in countries like France, Italy, and Spain, partly because of the 
relatively small size of Ireland and the limited development of regional products. Recognized products in Galway cuisine, traditionally, were lamb produced in the mountains of Connemara, salmon and shellfish from Galway Bay. Recently, there have been changes to this traditional consumption of food, including the incorporation of vegetables and organic produce as natural and healthy foods, which of course do have an association with geographical propinquity. In addition, current food trends include greater creativity and imagination in how ingredients are combined and presented: quality ingredients presented with flair. Finally, the incorporation of artisan food products from other European countries has occurred in response to growing interest due to increased international travel.

\section{METHODS AND SAMPLE}

Following review of recognized national food guides and the websites and menus of restaurants in Galway, six were identified which promote the use of local food in their kitchens (Fig. 4). Their seating capacity varied from $45-90$ persons. Interviews were conducted with a key decision-maker in sourcing food in each restaurant: the owner, the manager, or the head chef. In one case both the owner and the chef were interviewed because they were jointly influential in determining the menu. All interviewees are referred to anonymously as Chef 1 , Chef 2, etc., although several were managers or owners rather than chefs. The interview guide focused on the business profile and on the three research objectives. These components specifically allowed for gathering a broad range of information on chefs' perceptions and actions regarding local food, which illuminate the ways in which restaurants play a role in the development of local food value chains.

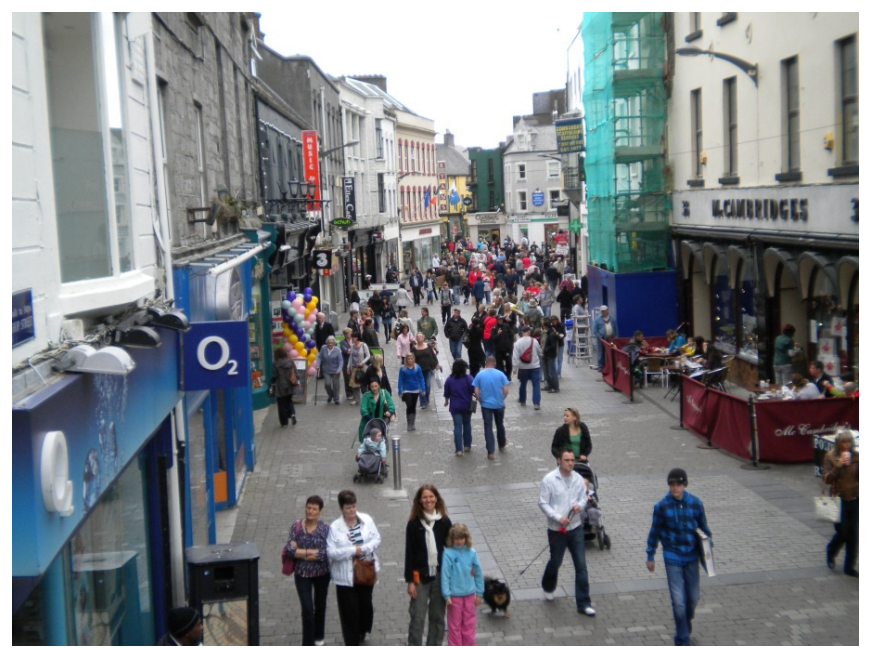

Fig. (4). Shop Street in Galway Ireland; all six surveyed restaurants are in close proximity to this main area of commerce.

The interviews were tape recorded and were supplemented with extensive notes. Copies of menus and of statements of objectives/philosophy were obtained, as was website material (when available). Thematic analysis of the interviews was undertaken and content analysis was conducted on the menus and the supplementary materials. A rich database of textual material was collected and analyzed from which clearly identifiable themes and sub-themes were identified relating to the meaning of local food and its use in the restaurants.

\section{Sample Profile}

Five male and two female chefs were interviewed. One was aged 45-54 years; the others were aged 25-34 years. Two held professional qualifications in cooking and in catering, respectively; the others held a range of other qualifications. With one exception, the restaurants were established in 2008-09, as economic recession was impacting in Ireland. This apparently inauspicious timing appeared to have been influenced by falling rents and properties becoming available. A deep interest in food, in local ingredients, and in demonstrating use of those ingredients were the reasons cited for opening and working in the restaurants, as described by one chef: "I wished to stay in Galway...to showcase food from round Galway. A lot of people are creating fantastic food and ingredients and no one is showcasing them in a proper way." (Fig. 5). The chefs are profiled briefly in order to contextualize the analysis of their narratives. They are numbered in order of interview.

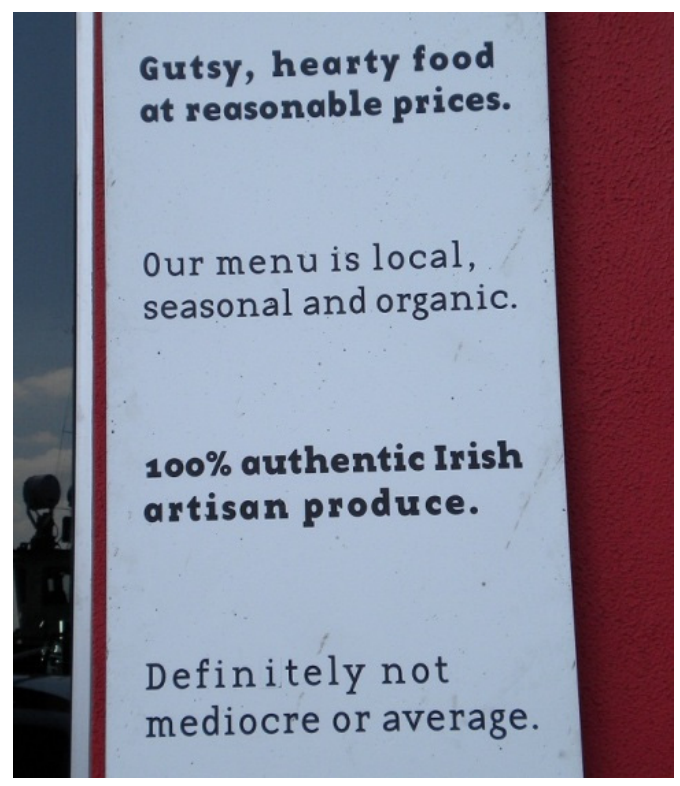

Fig. (5). Restaurant sign advertises their perceived importance of local and organic food.

Chef 1 has a clearly developed philosophical perspective on local food which influences the produce sourced and presented in his businesses. He had a broad mission that related to: "Trying to redefine cuisine from Ireland without being posh or 'Michelin Star' about it. Trying to define why we can produce and cook from the surrounding countryside." Several other interviewees acknowledged his role in creating awareness of artisanal food in Ireland. Chef 2 holds an arts degree, has held apprenticeships as a chef and worked in several different establishments and also has a clearly articulated approach to the use of local food. Chef 3 holds an arts degree and has previous experience as a chef. He and his wife opened their restaurant in 2009 and his niche strategy invokes the historical links between Galway and Old World Europe (Fig. 6). He has also established links with the arts community and provides courses in wine and food.

Chef 4 has a background in management in the food and catering sector and selected the name of his restaurant to convey the sense of local foods being used. He pointed out that it is difficult to source all produce locally but features 
organic produce on the menu. Chef 5 worked in the longestestablished of the restaurants (opened in the mid-1990s) and referred to the higher quality of local produce, to supporting local producers economically and to the convenience of having local suppliers. Chef 6 paralleled Chef 1, in owning more than one business and holding strong philosophical ideas relating to local food. Chef 6 has an eclectic style that is reflected in the restaurant, which incorporates both Irish and international cuisine. Chef 7 who works in a restaurant owned by an investor in the food and drinks sector, previously worked with Chefs 1, 3 and 6 and holds a degree in hotel and restaurant operations, as well as professional qualifications as a chef. The restaurant conveys a non-formal ambience and attracts a young clientele in the late evenings. It has a greater emphasis on using organic produce than have the others and a mission to use exclusively Irish food produce.

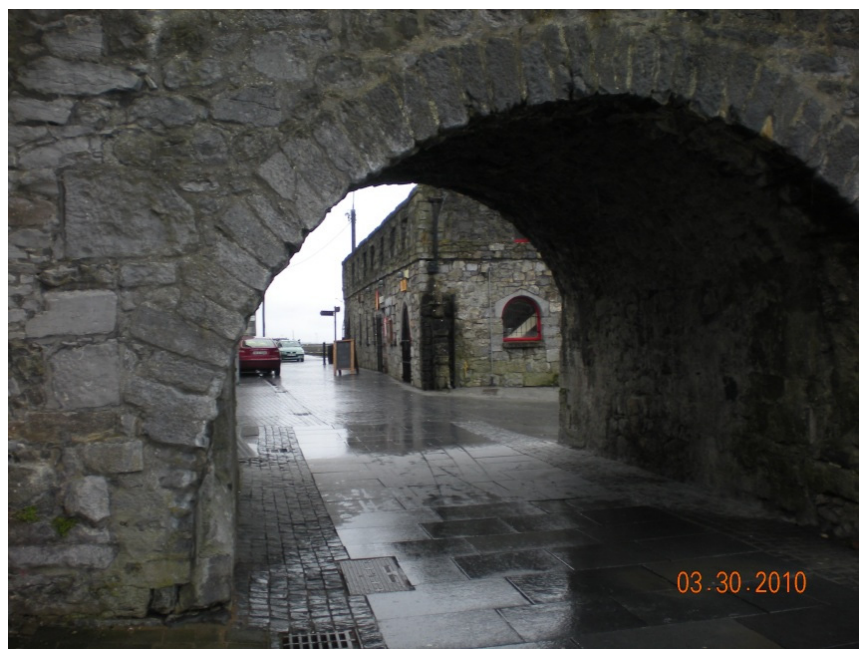

Fig. (6). Spanish Arch, built in 1584, represents historical influence of European trade with Ireland.

All of the restaurants were members of the professional representative group - the Restaurants Association of Ireland (RAI) - which involves an annual membership fee of $€ 700$ (US\$ 954.45; $€ 1=U S \$ 1.3635$ ) but provides access to reduced insurance costs and awards prizes to members. Three chefs were also members of professional networks which promote the use of local food, provide access to information and visibility to informed consumers nationally and internationally. These are Good Food Ireland which requires the use of $100 \%$ Irish beef and a commitment to increase the use of other Irish meat products on menus, the European chefs' association (Eurotôques) and the international Slow Food movement.

The restaurant prices for main courses may be considered high compared to many other eatery options in Galway. They varied from $€ 14$ (US\$19.09), in the informal restaurant, to $€ 30$ (US\$40.90) in the more formal restaurant. One chef referred to high prices being almost a necessary feature of quality during the years of the economic boom: "If you did not have a high price, you were not considered elitist enough." All reported that customer numbers had fallen during the on-going recession that began in 2008 and 2009 and meeting rental payments was a challenge for some. In response efforts were being taken to retain customers by introducing special lower cost "early bird" menus while still maintaining quality.

\section{RESULTS}

The results of the interview and text analyses are presented with reference to: (1) how local food was defined by the chefs and the motivation for using local food in the restaurant; (2) issues relating to the sourcing of this food; and (3) how local was used in cuisine and conveyed in menus.

\section{Conceptualizing Local Food}

A direct question about how a local food was defined elicited reference to the geographical origin of the food but also subsumed artisanal features which involved a geographical "stretching" of sources [17, 47]. There was a reluctance to define local as being associated with a particular distance from Galway, although many reported sourcing meat, fish, milk, eggs, some cheeses, bottled water and vegetable products within a radius of 100 kilometers $(60$ miles) from the city (Table $\mathbf{1}$ ).

Table 1. Definition of "Local" Food

City and County

In close proximity to where we are (Chef 3 )

Local to County Galway, County Mayo, in Ireland (Chef 6)

All fish from Galway Bay, all vegetable suppliers and butchers are Galway based (Chef 5)

Named producers in county Galway (Chef 4)

Ireland

The island of Ireland (Chef 1)

Artisan products: Local and International

Produced locally...vegetables and proteins from County Galway, rapeseed oil from Donegal, salt from Cornwall...(Chef 2)

Cannot define by distance or place because we don't have a network in Galway to source all "local" produce (Chef 7)

Chef 7 was conscious of deficiencies in supply in Galway, but expanded on the motivations of the producers and the qualities of local food: "The local food I get here is probably the best in Europe. The people that grow it are so passionate about growing it. I cannot really describe it. When you are actually cooking with this food you feel that it is actually going through you...the vitamins and the minerals you know." Chefs 2 and 7 reported foraging for wild berries and mushrooms in season, a time consuming activity, which points to a deep embeddedness locally. Most chefs also produced some of the foods used in the restaurants: bread, chutneys, marmalades and jams (Fig. 7). Chefs 1, 2, 6 and 7 highlighted their use of local produce most strongly but acknowledged that not all produce was sourced in the immediate environs of Galway due primarily to seasonality, availability and the price of some specialty products, reflecting structural obstacles identified in other studies (e.g., $[18,19])$.

Local food was extended to incorporate oil, apple juice, yogurt, specialty cheeses, charcuterie and ice cream sourced from artisan producers in other parts of Ireland. Only charcuterie was associated with a recognized food region - 
West Cork [50]. Local was also extended to include artisanal produce from other European countries, an international dimension less well documented in published literature. Grains, lentils, chickpeas and wines were sourced through specialty importers. Thus Chef 7 described: "Flour is organic...buy in England if cannot get in Ireland...organic pasta...barley from the UK." Two restaurants imported wine through agents who dealt with specialty producers in Italy, Spain and New Zealand.

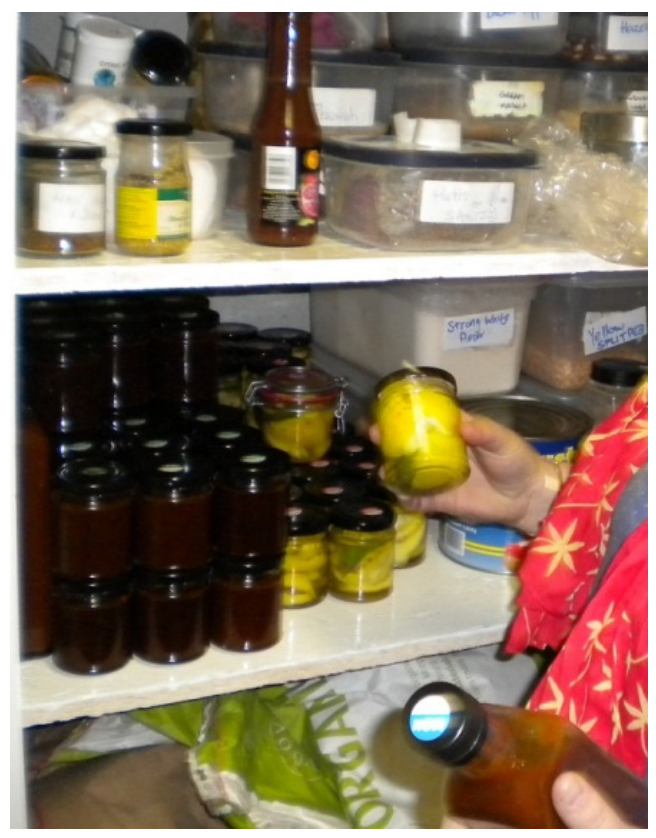

Fig. (7). Chutneys and preserves made by Chef 7.

The chefs' motivations for using local food included features relating to its use more generally: namely, the inherent quality of the food (mentioned by all), cost savings, supporting local producers and the benefits to the environment arising from the shorter distances travelled between the farm and the restaurant. Chef 2 summarized a list of reasons which highlight food quality and cost. A desire to support local producers financially during the current recession was mentioned by four, in a form of "defensive localism" [51] as noted by Chef 5: "I like to use local suppliers... give everyone a slice of the business...." However, Chef 3 reported the economic reality of needing to use the pricier Irish organic meat selectively for main courses and cheaper, imported (non-artisan) produce as ingredients for small dishes in response to differential consumer willingness to pay.

The advantages of using local food reflected both affective and practical issues. Local products are "more interesting, more of a challenge to use" (Chef 2). Others noted gaining recognition in food guides because of using local ingredients (Chef 3 ). Convenience was noted by Chef 5: "If ever stuck at the last minute, can call on local supplier...they come down straight away with produce." Obstacles to using local ingredients included a perception among some clientele that foreign produce and cuisine was "superior": "there is a 'foreign is better' view in Ireland" (Chef 2). In the words of another chef: "(initially) everything was 'foreign this', 'foreign that', 'Italian this', 'Italian that'." While this perception reflects a weakly developed sense of a quality local cuisine amongst customers, it also suggests that it is relatively easy for the chefs to construct a stretched concept of local food rather than one based only on less exotic geographical proximity. Chefs also referred to the challenge of paying immediately for produce from small scale producers, in contrast to a monthly account with a commercial supplier.

\section{Sources of Local Food}

Chefs discussed where they obtained their local food products by focusing on nearby producers and suppliers, and a small number of more distant artisanal producers in Ireland. Thus their description of local food sourcing was more geographically defined than their definitions of local food mentioned above. Indeed the social relationships and issues of trust were highlighted. Most of the restaurants used a limited number of the same producers in County Galway and adjoining counties who supplied them with meat, organic vegetables, and some cheeses. Three chefs sourced organic meat from a particular farm in the neighboring county and organic vegetables from a prize winning vegetable grower in eastern county Galway. The chefs reported that the producers had approached them with their products, rather than the other way around. This pro-active approach contrasts with evidence by Starr [16] in Colorado and reflects the confidence of the producers in the high quality of their produce. Chefs 4 and 5 reported purchasing vegetables from reliable wholesale suppliers, whom they trusted to provide them with local food when possible, rather than directly from the producers. This approach reduces the number of contacts that must be maintained and increases convenience and coincides with evidence from other countries (e.g., [9]). Meat was usually sourced from local family butchers. Most chefs purchased fish from reliable intermediaries in Galway and one chef explained a difficulty in purchasing directly from fishermen because one company effectively controls most of the wholesale fish market.

Some chefs had established good working relationships with producers, which were conducive to meeting specific requirements. Chef 2 referred to a producer of free range pork raising an animal breed in order to supply a certain type of meat that is desirable for the restaurants" customers: "We have a really good relationship with them; we discuss cross breeds to achieve a certain fat content in the meat. Same with lamb; good marbled lamb." The same chef spoke of the pork and lamb producer having told him about a farmer who produces pasture reared duck, indicating a referral network among the producers. Chef 7 used the same organic supplier of pork and also reported a close working relationship with this farmer: "Sausages are handmade by Connor's Farm in County Clare with free range pork. I ring up Sean and buy an organic free range pig." [Names changed to preserve anonymity.] Some respondents also referred to artisan cheese makers by name or in another familiar way, suggesting personal knowledge. Chef 6 , for example, was on friendly terms with several cheese makers and easily referred to them by first name and knew their specific geographical location.

Sourcing specialty products from more distant artisan producers in Ireland was not identified as being problematic, suggesting effective methods of distribution. In addition to 
ice cream, Irish cheeses were sourced over equally long distances through intermediaries and through the mail.

Some problems were identified associated with sourcing local produce, to which two responses emerged: replacement and adaptation. Additional cold storage was needed to compensate for less frequent deliveries of organic meat and vegetables by individual producers (Fig. 8). One chef referred to this factor and to price in rationalizing his shift from a local organic producer to a conventional wholesaler: "The larger multinational companies...could offer better prices, more discounts. We buy more from them now; better prices with same quality." (This contrasts sharply to other interviewees who felt there was clear superiority to local organic vegetables.) This same chef also said that sometimes he had to buy French- or Icelandic-caught fish in winter because of the non-availability of required species from Irish fishermen. By contrast, other chefs adapted their menu to the fish species that were available on a given day. Chef 7 referred to the sense of adventure in planning a menu in advance when aspiring to use local food: "At first I changed menu every day according to what we 'tripped over' in the boxes...cooking off the bat like that. That was brilliant...we did that for all of December and then it got to the 'like craggy months' of Winter" and they were forced to develop a set menu from more conventional wholesale suppliers.

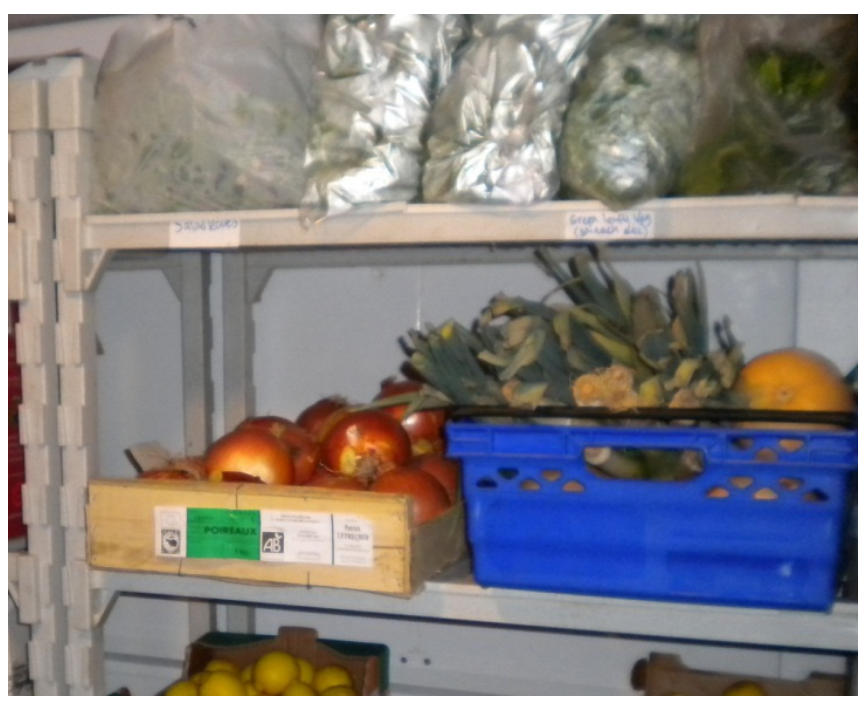

Fig. (8). Cold storage at restaurant includes both local "leaves" labeled on the top shelf and imported organic vegetables.

Other chefs referred to adapting the menu to the variety and seasonality of supply available. Specific dishes (usually soups) were based on seasonal vegetables. Game (grouse, pheasant and venison) was included on two menus in autumn and winter. Chef 5 featured game in winter and more fish and seafood in summer. Chef 2 elaborated: "It makes sense to use local food" because "I enjoy the variation...the challenge" of adapting the menu from day to day or season to season.

\section{Promotion of Local Food to Consumers}

The research differed from previous studies in analyzing how the use of local food was promoted in menus and websites and querying the influence of customers. Food was linked to place of production and producer in deliberate ways to create attributions of local and Irish and these varied according to the type of product. All of the restaurants' menus listed " $100 \%$ Irish beef" conveying a quality product, support for Irish farmers and compliance with Bord Bia [52] recommendations. One respondent explained that the term local was "not on menu...[rather conveyed] on the plate, waiting staff, word of mouth, and reviews" (Chef 2). He was reluctant to cite producer names unless they were used exclusively, although he sourced from individual organic meat producers. The menu cited meat as being "guaranteed Irish" and "locally sourced" and "Irish artisan cheeses" were listed. Chef 6's menu which features Irish and international cuisine invoked geographically local and regional sourcing and conveyed personal relationships with producers. Dishes included "Galway mackerel," "Burren smoked trout," "local clams," and "Irish cheese." A personalization of production and possibly support for individual producers was implied through friendly references to "Fionn the fisherman" and "O'Malley's steak." [names changed for anonymity]. The chef said that the restaurant was perceived as being "organic" because they used some organic produce, although they did not do so exclusively and did not seek to create that impression. Another restaurant which was establishing a reputation for European regional produce and highlighted imported, directly sourced, artisanal food, meats and cheeses, also listed "Irish rack of lamb" and "ethical, organic" produce on its menu.

One restaurant listed its local intermediary suppliers of meat and fish. Another restaurant listed "Atlantic" fish, which implied local sourcing, but the owner admitted that less than $10 \%$ of the food they serve is actually produced locally. The menu avoided reference to Irish or local produce, except in the case of cheeses. The chef said that naming sources had become "clichéd," but his wholesale sourcing meant that he was less likely to know specific farmers or list them on the menu. Imperfect knowledge of the meaning of organic and local among some customers may serve to undermine demand for geographically local produce.

The use of local food on menus responded in part to consumer demand, which was divided between $60 \%$ local and Irish customers and 40\% overseas tourists. Local customers were attributed particular influence (Table 2). The positioning of the restaurants as mid-priced or moderate rather than low priced also reflects catering to a discriminating upscale market with some disposable income, although dining out has declined since the economic recession began in 2008. Chef 1 described the range of clientele whom his restaurant attracts: "We get ordinary people for birthdays, anniversaries...(and are) frequented by wealthy doctors and barristers [attorneys] who can afford to eat here once a week...we are a restaurant for a special occasion where we put a lot of effort into the food."

The methods of advertising the use of local food included informal and formal media (Table 3). A nomination for the Irish Restaurant of the Year award, from the RSA, was cited as an important source of publicity. Being mentioned in critical guides was said to be the most important source of information for clients but the plaques awarded involve a fee of $€ 500$ (Fig. 9). Chef 5 promoted organic produce as part of the annual Organic Week (sponsored by Bord Bia). Chef 7 
referred to having joined Good Food Ireland, having a Facebook site, and to developing a web site.

Table 2. Consumer Influence on Use of "Local" Food in Cuisine and Menus

I think local food is important with locals...not sure that tourists are too worried about where produce comes from (Chef 5)... being more interested in its quality features

I change the menu with the seasons. A lot of customers like to see that We are not really relying on a tourist market. (Chef 4)

The customers want to learn about food and wine. If they only want to eat, they probably go elsewhere. They come here for the

experience...pairing of good food and wine (Chef 3 , who specializes in European foods and uses some Irish local produce)

We are really the only ones in town doing it properly....everything is so vibrant because the food is from here...carrots, pumpkin mayonnaise, parsnips in cakes (Chef 7)

\section{Table 3. Methods of Promoting Use of "Local" Food}

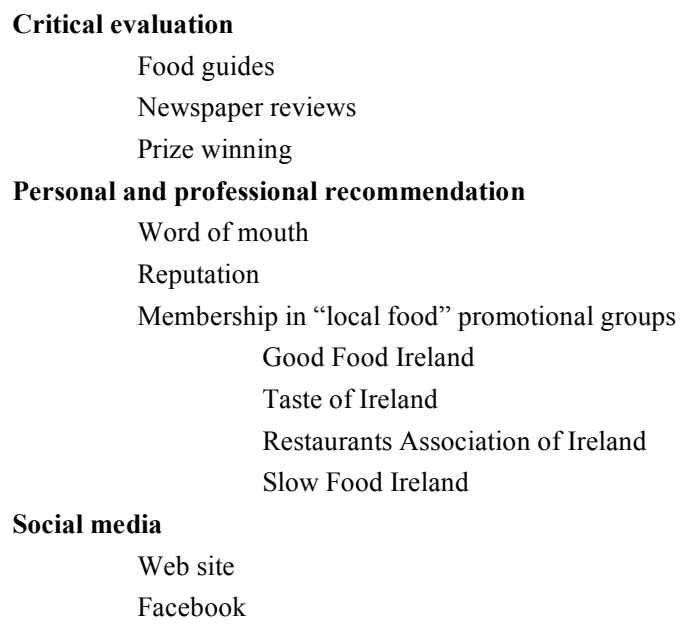

Personal and professional recommendation

Word of mouth

Reputation

Membership in "local food" promotional groups Good Food Ireland

Taste of Ireland

Restaurants Association of Ireland

Slow Food Ireland

Social media

Web site

Facebook

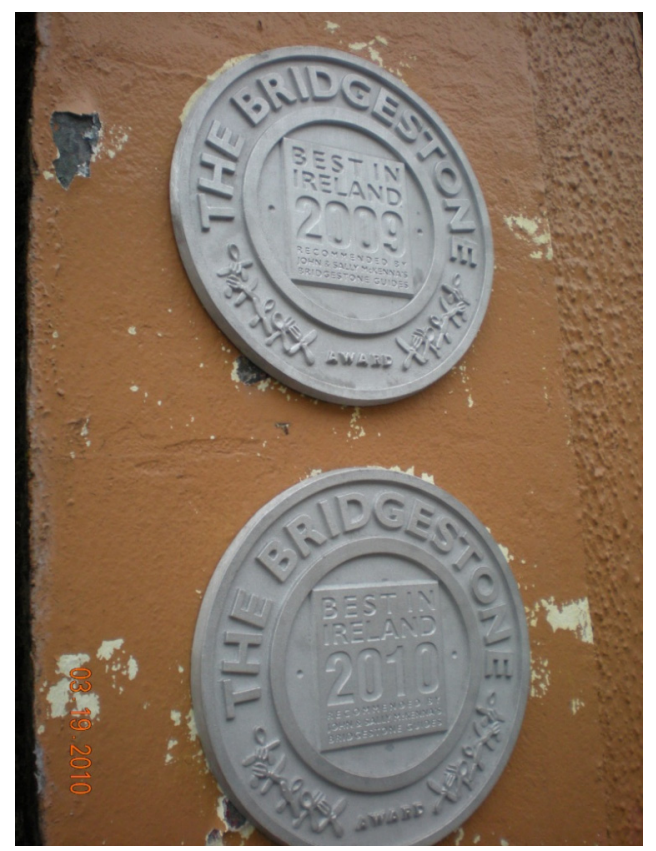

Fig. (9). Example of the award plaques which may be displayed if a restaurant owner pays a significant fee.

\section{DISCUSSION AND CONCLUSIONS}

Several themes emerge, which characterize chefs and restaurants seeking to build interest in local foods to further strengthen shortened food value chains (Table 4). Despite variations in individual definitions, the de facto sourcing of local food included products produced within a radius of 100 kilometers $(60$ miles). Chefs also incorporated artisan produce sourced from recognized processors elsewhere in Ireland and even stretched local to include artisan produce from outside Ireland. These scale dimensions have implications for the market opportunities of small scale producers in the immediate environs of the restaurants. Some opportunities exist that can be built upon, even in a small city with both a local and tourist market, during a recession when consumer restaurant spending is reduced. As in many locations, there is an absence of a regional cuisine or Irish food culture [53]. This has implications for chefs' capacity to base menus exclusively on food produced nearby.

Table 4. Characteristics of Chefs Within the Local Food Value Chain

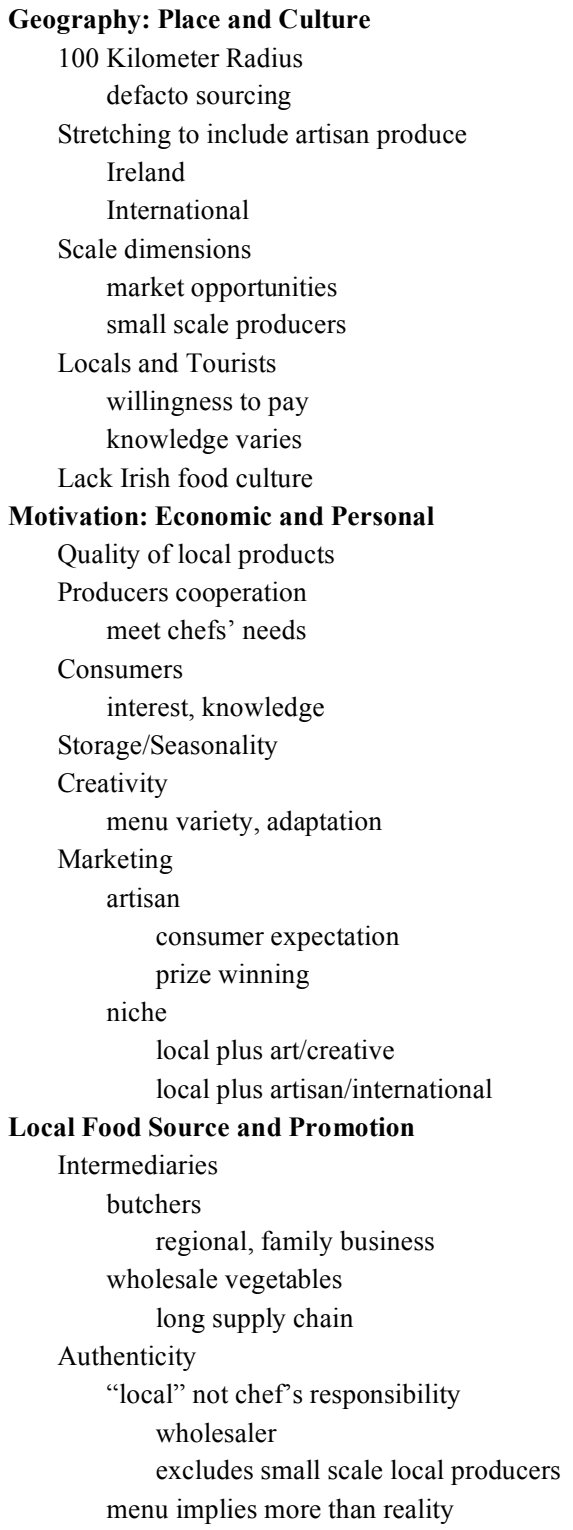


The use of local produce is determined by the motivation of the chef, who in turn is influenced by: the quality of the available produce, the willingness of producers to meet special requirements, capacities for storage, and the prices that consumers are willing to pay. Seasonality may be used in creative ways by committed chefs to incorporate a high proportion of authentically local items in menus, throughout the year. Even when chefs are deeply committed to using food grown and processed locally, artisan products may be imported from outside the immediate area or from overseas for particular dishes and to meet consumer expectations. The reputation of artisan producers serves as a guarantee of quality and trusted intermediary importers are used. The ability of restaurants to create a menu with a substantial proportion of geographically local food also requires a clientele who have the interest and willingness to pay for this cuisine. Sometimes, differentiation may be sought through methods of cooking and the use of condiments to create more exotic dishes. A restaurant may participate in the stretching of local food to incorporate artisanal food in order to create a differentiated market niche. Such restaurants may, however, also feature quality local and Irish artisan food on the menu to appeal to a broader range of consumer taste and provide some opportunities for local producers.

Variation in the use of intermediaries ("middlemen") exists between meat and vegetables. Because of a need for additional storage facilities arising from infrequent deliveries, the time required to deal with multiple producers and cost, some chefs prefer to rely on local butchers almost exclusively for meat (who guarantee Irish and usually local production). On the other hand, intermediary wholesalers may be the sources of vegetables, which often come from farther afield. The responsibility for sourcing locally is, in this case, devolved to the intermediary, who is purchasing in large quantities to meet demand from a range of businesses. Small scale local vegetable producers may be unable to meet the requirements of such a wholesaler, so larger scale commercial producers would gain instead. By not referring to their wholesalers on menus/websites, restaurants may create an impression of sourcing from small-scale producers. This practice does a disservice to the latter, and raises the issue of authenticity. Chefs who source vegetables directly from local producers represent an authentic use of promoting such foods on their menus, as they may list "Greens from Farmer Padraig's Farm," for example. This authentic promotion and use of locally produced products supports local producers more effectively, which creates a stronger local food value chain.

Chefs vary significantly in their perceptions of local food, their geographical patterns of sourcing these foods, and their promotion of local food on menus. To overcome such variation, promote the authentic use of local food in restaurants, and build stable local food value chains, several strategies may be undertaken (Table 5): (1) better certification and labeling to verify the authenticity of local and regional foods for consumers; (2) marketing assistance to local farmers to specifically address farmer-to-chef linkages and develop this outlet for small scale producers; (3) programs to incorporate producers, consumers, and chefs into local food networks to build long term goals and actions, e.g., a Food Policy Council [4]; (4) a designation by professional organizations for restaurants that source directly from producers, e.g., a "Local Items in our Kitchen Extensively" (LIKE) award that restaurants can apply for and advertise; and (5) education and linkages to Fair Trade to guide chefs in sourcing food/drink from small scale producers located farther afield.

Chefs are indeed revalorizing "local" in the cuisine that they serve which may involve products that are not per se "alternative" but the provenance of which is more closely sourced than in the past. This is partly in response to consumer concerns relating to the overuse of pesticides and insecticides in more conventionally produced food. In this context "local" is equated with traceable and "healthy". Chefs are also responding to growing interest among some consumers in associations with place and "terroir" in the food that they consume. This is an indicator of their personal knowledge about food and cultural capital. For chefs, local may or may not be promoted as an alternative; instead, local is a more deliberate niche strategy which may be partly based in a philosophy of food among certain chefs.

The results of this study highlight the role of an under researched link in the local food value chain. These findings are likely relevant in other geographical areas which lack a well-developed regional cuisine or long-established food culture. Restaurants clearly play important functions in constructing geographies of local food that are worthy of further research for both academic and practical reasons. Chefs and their restaurants are taste makers, and their conceptualizations of local food can influence society as a whole.

Table 5. Strategies to Build Farmer-to-Chef Local Food Value Chains

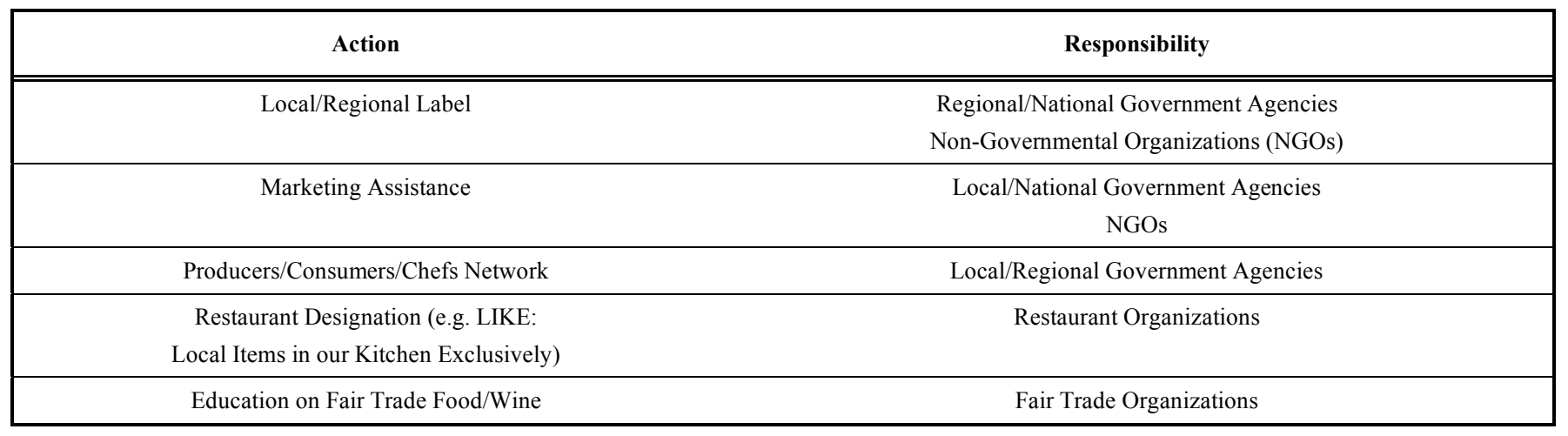




\section{ACKNOWLEDGEMENT}

The chefs who kindly participated in interviews and provided written materials for analysis; Dr. Siubhan Comer, Department of Geography, NUI Galway for Figure 1; the US Fulbright Scholar Program and the Fulbright Commission in Ireland.

\section{CONFLICT OF INTEREST}

Declared none.

\section{REFERENCES}

[1] Winter M. Geographies of food: agro-food geographies-making connections. Prog Hum Geogr 2003; 27(4): 505-13.

[2] Morris C, Buller H. The local food sector: a preliminary assessment of its form and impact in Gloucestershire. Br Food J 2003; 105(8): 559-66.

[3] Eden S, Bear C, Walker G. Mucky carrots and other proxies: problematising the knowledge-fix for sustainable and ethical consumption. Geoforum 2008; 39(2): 1044-57.

[4] Duram LA, Ed. Encyclopedia of organic, sustainable and local food. Santa Barbara: Greenwood Press (Praeger) 2010; p. 440.

[5] Watts DCH, Ilbery B, Maye D. Making reconnections in agro-food geography: alternative systems of food provision. Prog Hum Geogr 2005; 29(1): 22-40.

[6] Hinrichs C. Embeddness and local food systems: notes on two types of direct agricultural market. J Rural Stud 2000; 16(3): 295303.

[7] Maye D, Holloway L, Kneafsey M, Eds. Alternative food geographies: Representation and practice. London: Elsevier 2007.

[8] Feagan R. The place of food: mapping out the "local" in local food systems. Prog Hum Geogr 2007; 31: 23-42.

[9] Inwood SM, Sharp JS, Moore RH, Stinner DH. Restaurants, chefs and local foods: insights drawn from application of a diffusion of innovation framework. Agric Human Values 2009; 26(3): 177-91.

[10] McNamee, T. Alice Waters and Chez Panisse: the romantic, impractical, often eccentric, ultimately brilliant making of a food revolution. Penguin Press: New York, USA 2008; p. 400.

[11] Moskin, J. Reclaiming Ireland's culinary heritage, one roast lamb or sponge cake at a time. New York Times, 2010. Available from: http://www.nytimes.com/2010/03/31/dining/31 Irish.html

[12] Zelinsky W. The roving palate: North America's ethnic restaurant cuisines. Geoforum 1985; 16(1): 51-72.

[13] Bell D, Valentine G. Consuming geographies: we are where we eat. Routledge: London, UK 1997.

[14] Shortridge BG, Shortridge JR. The taste of American place: a reader on regional and ethnic foods. Rowman and Littlefield: Maryland, USA 1998.

[15] Spang RL. The Invention of the restaurant: Paris and modern gastronomic culture; Harvard University Press: Massachusetts, USA 2000.

[16] Starr A, Card A, Benepe C, et al. Sustaining local agriculture: barriers and opportunities to direct marketing between farms and restaurants in Colorado. Agric Human Values 2003; 20(3): 301-21.

[17] Ilbery B, Maye D. Retailing local food in the Scottish-English Borders: a supply chain perspective. Geoforum 2006; 37(3): 35267.

[18] Curtis KR, Cowee MW. Direct marketing local food to chefs: chef preferences and perceived obstacles. J Food Distrib Res 2009; 40(2): 26-36.

[19] Sims R. Putting place on the menu: The negotiation of locality in UK food tourism, from production to consumption. J Rural Stud 2010; 26(2): 105-15.

[20] Sonnino R, Marsden T. Beyond the divide: rethinking relationships between alternative and conventional food networks in Europe. J Eco Geogr 2006; 6(2): 181-99.

[21] Smith A, MacKinnon JB. The 100 mile diet: a year of local eating; Random House: Toronto, Canada 2007.

[22] Ricketts Hein J, Watts D. Local food activity in the Republic of Ireland and Great Britain. Irish Geogr 2010; 43(2): 135-47.
[23] Illinois Local and Organic Food and Farm Task Force. Illinois Department of Agriculture. Available from: www.agr.state.il.us/marketing/Mkt_ILOFFTaskForce.html

[24] New York State Council on Food Policy. Creation \& mission of the NYS Council on Food Policy. Available from: www.nyscfp.org/

[25] Ilbery B, Kneafsey M. Niche markets and regional specialty food products in Europe: towards a research agenda. Environ Plann A 1999; 31(12): 2207-22.

[26] Marsden T, Smith E. Ecological entrepreneurship: Sustainable development in local communities through quality food production and local branding. Geoforum 2005; 36 (4): 440-51.

[27] Duram LA, Oberholtzer L. A geographic approach to examine place and natural resource use in local food systems. Renew Agric Food Syst 2009; 25(2): 99-108.

[28] Weber CL, Matthews HS. Food-miles and the relative climate impacts of food choices in the United States. Environ Sci Tech 2008; 42(10): 3508-13.

[29] Offer A. Between the gift and the market: the economy of regard Econ Hist Rev L 1997; (3): 450-76.

[30] Duram LA. Good growing: why organic farming works. University of Nebraska Press: Nebraska, USA 2005.

[31] Donald B, Blay-Palmer A. The urban creative-food economy: producing food for the urban elite or social inclusion opportunity? Environ Plann A 2006; 38(10): 1901-20.

[32] Blake MK, Mellor J, Crane L. Buying local food: shopping practices, place, and consumption networks in defining food as "local." Ann Assoc Am Geog 2010; 100(2): 409-26.

[33] Cawley M, Gaffey S, Gillmor DA. Localization and global reach in rural tourism: Irish evidence. Tourist Stud 2002; 2(1): 63-86.

[34] Miele M, Murdoch J. The practical aesthetics of traditional cuisines: slow food in Tuscany. Sociol Ruralis 2002; 42(4): 312-28. Buck D, Getz G, Guthman J. From farm to table: the organic vegetable commodity chain in Northern California. Sociol Ruralis 1997; 37(1): 1-20.

[36] Guthman J. Fast food/organic food: reflexive tastes and the making of "yuppie chow". Soc Cultural Geogr 2003; 4(1): 45-58.

[37] Hinrichs C. The practice and politics of food system localization. J Rural Stud 2003; 19(1): 33-45.

[38] Tovey H. "Local food" as a contested concept: networks, knowledges and power in food-based strategies for rural development. Int J Sociol Agric Food 2009; 16(2): 21-35.

[39] Banks J, Bristow G. Developing quality in agro-food supply chains: a Welsh perspective. Int Plan Stud 1999; 4(3): 317-31.

[40] Weatherell C, Tregear A, Allison J. In search of the concerned consumer: UK public perceptions of food, farming and buying local. J Rural Stud 2003; 19(2): 233-44.

[41] Cawley M, Commins P, Gaffey S, et al. Quality Irish regional products and services: their promotion and marketing. Irish findings of European Commission FAIR3-CT96-1827 project. RIPPLE; National University of Ireland, Galway and Teagasc: Galway and Dublin, Ireland 2004.

[42] Roininen K, Arvola A, Lähteenmäki L. Exploring consumers' perceptions of local food with two different qualitative techniques: laddering and word association. Food Qual Pref 2006; 17(1-2): 2030.

[43] Lappé FM. Food, farming and democracy. In: Clark R, Ed. Our Sustainable Table. San Francisco: North Point Press 1990; pp. 14359 .

[44] Murdoch J, Miele M. "Back to nature": changing "worlds of production" in the food sector. Sociol Ruralis 1999; 39(4): 465-83.

[45] Murdoch J, Marsden T, Banks J. Quality, nature and embeddedness: some theoretical considerations in the context of the food sector. Econ Geogr 2000; 72(6): 107-25.

[46] Connell DJ, Smithers J, Joseph A. Farmers Markets and the "good food" value chain: a preliminary study. Local Environ. Int J Justice Sustainability 2008; 13(3): 169-86.

[47] DuPuis E M, Goodman D. Should we go "home" to eat? Toward a reflexive politics of localism. J Rural Stud 2005; 21(3): 359-71.

[48] EU PGI. European Commission: Agriculture and Rural Development. EU agricultural product quality policy. Protected Geographical Indication (PGI) for agricultural farm products and foodstuffs 2011. Available from: http://ec.europa.eu/agriculture/quality 
[49] Cowan C, Sexton R. Ireland's traditional foods: an exploration of Irish local \& typical foods \& drink. Teagasc; The National Food Centre: Dublin, Ireland 1997.

[50] Sage C. Social embeddedness and relations of regard: Alternative "good food" networks in south-west Ireland. J Rural Stud 2003; 19(1): 47-60.
[51] Winter M. Embeddedness, the new food economy and defensive localism. J Rural Stud 2003; 19(1): 23-32.

[52] Bord Bia. Irish Food Board. About us, 2011. Available from: www.bordbia.ie

[53] Fonte, M. Knowledge, food and place: a way of producing a way of knowing. Sociol Ruralis 2008; 48(3): 200-22.

Received: February 4, 2012

Revised: April 6, 2012

Accepted: April 13, 2012

(C) Duram and Cawley; Licensee Bentham Open.

This is an open access article licensed under the terms of the Creative Commons Attribution Non-Commercial License (http://creativecommons.org/licenses/by$\mathrm{nc} / 3.0 /$ ) which permits unrestricted, non-commercial use, distribution and reproduction in any medium, provided the work is properly cited. 